\title{
The Accuracy of Interleukin-6 Urine Compared to Urine Culture to Diagnose Pyelonephritis in Neonates
}

\author{
Nezman Nuri*, Oke Rina Ramayani, Rafita Ramayati, Nelly R, Rosmayanti Syafriani Siregar and Beatrix Siregar \\ Department of Child Health, University of Sumatera Utara, Indonesia
}

Submission: December 17, 2016; Published: February 27, 2017

*Corresponding author: Nezman Nuri, Department of Child Health, University of Sumatera Utara, Indonesia, Email: nezmannuri80@gmail.com

\begin{abstract}
Background: Pyelonephritis is an infection that is common to all children in all age groups, including the newborn period. The diagnosis of urinary tract infection is established with certainty by urine culture. Additional investigations can be done to help confirm the diagnosis, such as Interleukin-6 urine (IL-6). Increased number of IL-6 urine is useful to help quickly checks the occurrence of pyelonephritis.

Objective: To assess the sensitivity and specificity of IL-6 urine examination for detecting pyelonephritis in neonates compared with urine culture.

Results: During study period, 45 neonates with positive urine cultures and 15 with negative cultures. Mean of ages was 8.35 days (SD 6.8), Mean birth weight was 2530.50 grams (SD 712.7), section caesarean delivery was 27 (45\%), vaginal delivery was 33 (55\%). Klebsiella pneumonia was the most common cause (46.6\%), Streptococcus agalactie (26.6\%) and Chryseomonasluteola (10\%). Interleukin-6 Urine level $>5.584 \mathrm{pg} / \mathrm{ml}$ considered as positive and $\leq 5.584 \mathrm{pg} / \mathrm{ml}$ considered negative. Sensitivity was $53.3 \%$, Specificity was $53.3 \%$, Positive predictive value was $69.5 \%$, Negative predictive value was $36.3 \%$, Likelihood ratio positive was 1.14 and Likelihood ratio negative was 0.87 in the examination of IL- 6 urine compared to urine culture.
\end{abstract}

Conclusion: IL-6 urine examination has a low accuracy to diagnose pyelonephritis in the neonates.

Keywords: Pyelonephritis; Neonates; Urine culture; IL-6 urine

Abbreviations: IL-6: Interleukin-6; CRP: C-Reactive Protein; TNF- $\alpha$ : Tumor Necrosis Factor- $\alpha$; IL-1 $\beta$ : Interleukin-1 $\beta$

\section{Introduction}

Urinary tractinfection is an infection that is often encountered in children in all groups of age, including the newborn period [1]. Based on the research at Cipto Mangunkusumo Hospital in 2004, the prevalence of urinary tract infection in neonates $14.9 \%$ [2], where the boy was more dominant compared with girl (between 2:1 and 6:1) because the possibility of an increasing incidence of structural abnormalities. In the group of preterm neonates, the prevalence ranges from $4 \%$ to $25 \%$. Early diagnose is very important to maintain the function of the developing kidney.

On infants these symptoms typically got fever, irritability or other symptoms such as lethargy [3]. Accurate diagnose and early treatment of pyelonephritis are important because the risk of renal scarring, hypertension and renal failure. It is important to distinguish the upper urinary tract infections and lower part, due to involvement of the renal parenchyma which can lead to kidney failure and chronic renal failure harvesters [4].
The diagnosis of urinary tract infection must be implementedby urine culture. Various investigations can be done to help making a diagnose such as leukocyte esterase, nitriurin, leukocytosis, an increasing the absolute value of neutrophils, an increasing erythrocyte sedimentation rate, C-reactive protein (CRP), procalsitonin level, tumor necrosis factor- $\alpha$ (TNF- $\alpha$ ), IL-6 urine, and Interleukin-1 $\beta$ (IL-1 $\beta$ ) [5].

An increasing number of IL-6 urine is useful as a quick examination occurrence of pyelonephritis. This is very useful especially in the case of pyelonephritis in which the clinical manifestations seldom apparent, therefore, with a rapid examination and accurate results then the treatment of pyelonephritis can be rapidly established and treated so that complications such as renal scarring, which can lead to hypertension and renal insufficiency can be avoided [6]. 
The aim of our study is to assess the sensitivity and specificity of IL-6 urine examination for detecting pyelonephritis in neonates compared with urine culture.

\section{Materials and Methods}

\section{Design study and sample}

The study was a cross sectional study which assesses the sensitivity and specificity examination IL-6 urine compared to urine culture in neonates with suspect of urinary tract infection. The experiment was conducted in the perinatology unit and neonatal intensive care units, Haji Adam Malik Hospital Medan for 3months starting November 2013 - January 2014. All subjects of research was requested informed consent from their parents after the first explanation of the disease conditions experienced which examination will be conducted. The study was approved by the Medical Ethics Committee of the Faculty of Medicine, University of Sumatra Utara. The total research sample that met the inclusion and exclusion criteria were 60 children, which then examined urine culture and IL-6 urine.

\section{Sample collection procedures}

Subjects collected in consecutive sampling. We conducted the examination of urine by taking urine used traditional infant urine collector bag. Urine samples obtained after examination of urine levels of IL-6 and examination of urine culture were performed in hospital Clinical Pathology division Haji Adam Malik Medan. The examination results were compared between neonates that discovered the existence of IL- 6 urine by the growth of bacteria in the urine.

\section{Statistical analysis}

The collected data will be processed, analyzed, and presented using SPSS ver.22 program to assess the sensitivity, specificity, positive predictive value, negative predictive value, positive likelihood ratio and negative likelihood ratio IL-6 urine compared urine culture in the diagnosis of pyelonephritis on infant diagnostic test.

\section{Results}

The total study sample that met the inclusion and exclusion criteria were 60 children, which then examined urine culture and IL-6 urine. Retrieved a sample of 60 neonates who consisted of 45 neonates with positive culture consisting of 30 positive urine bacterial cultures, fungal culture positive urine 15 and 15 neonates without bacterial or fungal growth in urine culture.

The average age of the sample was 8.35 days. Average birth weight 2530.50 grams and the most type of delivery was pervaginam. The most term gestation. Common clinical symptoms was fever and lethargy (Table 1).

Table 1: Demographic data of subjects.

\begin{tabular}{|c|c|}
\hline Characteristics & $n=60$ \\
\hline Neonatal age (days), mean (SD) & $8.35(6.8)$ \\
\hline Maternal age (years), mean (SD) & $26.07(3.3)$ \\
\hline Paternal age (tahun), mean (SD) & $27.75(3.3)$ \\
\hline Birth weight (gram), mean (SD) & $2530.50(712.7)$ \\
\hline \multicolumn{2}{|c|}{ Gestational age, $\mathbf{n}(\%)$} \\
\hline Preterm & $9(15)$ \\
\hline Term & $51(85)$ \\
\hline Post date & $0(0)$ \\
\hline \multicolumn{2}{|c|}{ Type of delivery, n(\%) } \\
\hline Caesarian & $27(45)$ \\
\hline Vaginal & $33(55)$ \\
\hline \multicolumn{2}{|c|}{ Clinicals symptoms, n(\%) } \\
\hline Fever & $42(70)$ \\
\hline Lethargy & $25(41.6)$ \\
\hline Jaundice & $5(8.3)$ \\
\hline Vomitus & $3(5)$ \\
\hline
\end{tabular}


Table 2 showed the most infections caused by Klebsiella pneumoniae (46.6\%), Streptococcus Agalactie (26.6\%) and Chryseomonas luteola 3(10\%) (Table 2).

Table 2: Prevalence of micro-organisms causing pyelonephritis in neonates.

\begin{tabular}{|c|c|}
\hline Microorganism & $\mathbf{n}(\%)$ \\
\hline Klebsiella pneumonia & $14(46.6)$ \\
\hline Streptococcus agalactie & $8(26.6)$ \\
\hline Chryseomonas luteola & $3(10)$ \\
\hline Streptococcus pyogenes & $2(6.6)$ \\
\hline Streptococcus faecalis & $1(3.3)$ \\
\hline Streptococcus saphrophyticus & $1(3.3)$ \\
\hline Enterobacter cloacae & $1(3.3)$ \\
\hline Total & $30(100)$ \\
\hline
\end{tabular}

The cutoff point is obtained by using curve Receiver Operator Curve because distribution data was abnormal. IL- 6 urine value $>5.584$ that used is the result of IL- 6 urinary on bacterial urine culture results positive and $<5.584$ negative (Table 3 ).

Table 3: The relationship urine culture examination with IL-6 urine.

\begin{tabular}{|c|c|c|c|c|c|}
\hline & & \multicolumn{4}{|c|}{ Urine Culture } \\
\hline & & \multicolumn{2}{|c|}{ Positive } & \multicolumn{2}{c|}{ Negative } \\
\hline & n & (\%) & n & (\%) \\
\hline $\begin{array}{c}\text { IL-6 } \\
\text { Urine }\end{array}$ & Positive & 16 & 35.5 & 7 & 15.5 \\
\hline & Negative & 14 & 31.1 & 8 & 17.8 \\
\hline & Total & 30 & 66.6 & 22 & 33.3 \\
\hline
\end{tabular}

ROC curves obtained from the boundary value IL-6 urine is 5.584 (Figure 1).

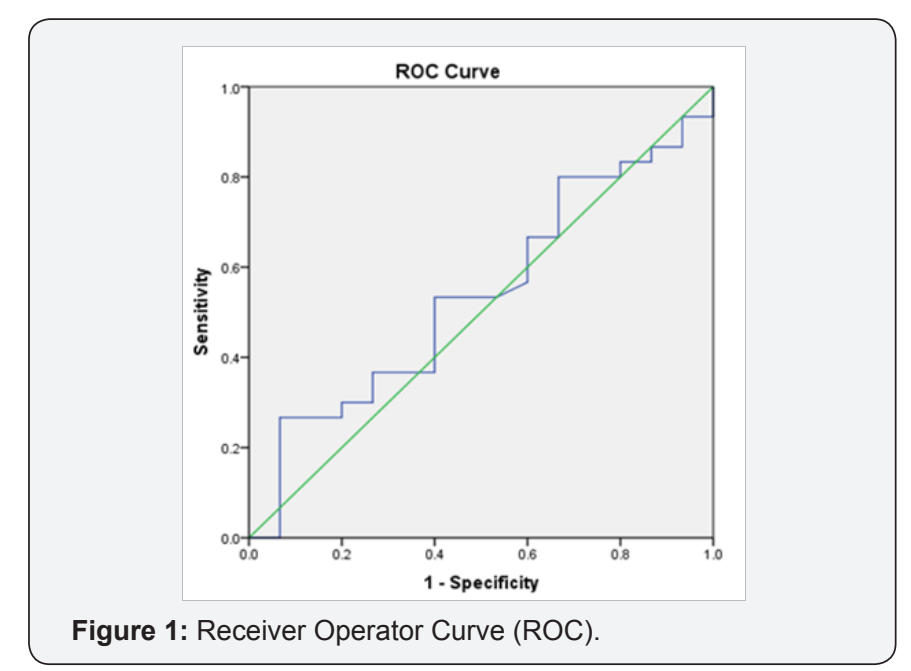

Sensitivity, Specificity, Positive Prediction Value (PPV), Negative Prediction Value (NPV), Positive Likelihood Ratio (LR+) and Negative Likelihood Ratio (LR-) IL-6 urine examination in the diagnosis of pyelonephritis in neonates (Table 4).
Table 4 showed that IL-6 urine examination can detect pyelonephritis was $53.3 \%$ and excluding the diagnosis of pyelonephritis was $53.3 \%$ in neonates with assumption of pyelonephritis. The possibility of neonates suffering from pyelonephritis was $69.5 \%$ and the possibility of not suffering from pyelonephritis was $36.3 \%$ after examination of IL-6 urine. The ratio possibility of infants with pyelonephritis compared to healthy infants after examination of IL-6 urine positive was 1.14 and the ratio of infants with pyelonephritis compared to healthy infants after examination of IL-6 urine negative was 0.87 (Table 4).

Table 4: IL-6 urine examination in the diagnosis of pyelonephritis in neonates

\begin{tabular}{|c|c|c|c|c|c|c|}
\hline Variable & $\begin{array}{c}\text { Sensitivity } \\
\text { (\%) }\end{array}$ & $\begin{array}{c}\text { Specificity } \\
\text { (\%) }\end{array}$ & $\begin{array}{c}\text { PPV } \\
\text { (\%) }\end{array}$ & $\begin{array}{c}\text { NPV } \\
(\%)\end{array}$ & $\begin{array}{c}\text { LR+ } \\
\text { (\%) }\end{array}$ & $\begin{array}{c}\text { LR- } \\
\text { (\%) }\end{array}$ \\
\hline IL-6 Urine & 53.3 & 53.3 & 69.5 & 36.3 & 1.14 & 0.87 \\
\hline
\end{tabular}

\section{Discussion}

IL-6 urine sensitivity and specificity to establish diagnose of pyelonephritis in neonates examined by urine sample examination. The urine sample collection selected by using infant urine collector bag because this technical of collection is not invasive and Infant urine bag collector is the technical of urine collection approved in AAP 2007 to establish the diagnose of urinary tract infection in neonates [7].

Urine sample collected by using infant urine bag collector, it declared significant if found bacterial growth $>50000$ colonies/ $\mathrm{ml}$ compared with supra pubic aspiration if one bacterial stated positive or with urinary catheterization when encountered bacterial growth $>10000$ colonies/ml declared significant $[8,9]$.

The number of colony growth in urine cultures expressed significantly by using infant urine collector bag when encountered growth of organisms $>50000$ colonies $/ \mathrm{ml}$ based on the revised AAP in 2007 [7], where previously stated colony growth significantly when bacterial growth $>105$ colonies $/ \mathrm{ml}$ [10].

In infant with illness and found the growth of the organism colonization of $>50000$ colonies $/ \mathrm{ml}$ has been declared in a complex urinary tract infection and can be diagnosed as pyelonephritis [7], despite will need to be proved by examination of DMSA scans (Dimercaptosuccinic acid) which shows that there are areas that take up the cortex contrast is reduced [11], estimated as pyelonephritis, although this is rarely needed in fact due to the cost and risk of radiation exposure on neonates [12].

Escherichia coli is responsible for about $80 \%$ of pyelonephritis, other organisms such as Proteus, Enterococcus, Pseudomonas and Klebsiella Sp, Staphylococcus aureus and Staphylococcus epidermidis $[13,14]$, our study showed the most bacterial infection caused by Klebsiella pneumoniae (46.6\%), Streptococcus agalactie (26.6\%) and Chryseomonas luteola $(10 \%)$. 
Based on the study Candida Yeast cell growth for 15 of 60 samples this may be caused by the use of swaddling in infants that causes fungal colonization and growth of bacteria that may be risk factors for Candida pyelonephritis in neonates. Clinically kidney damages normally more severe emerge on infants with low body resistance [15].

On the research in Denver in 2010, IL-6 urine increased within 6 hours after the occurrence of the infection process with the sensitivity of $88 \%$ [16], whereas in the research found a sensitivity of $53.3 \%$ and $53.3 \%$ specificity, this is due to differences in the number of samples in which the previous research of samples obtained by 25 neonates whereas in this research was obtained from a sample of 45 neonates.

On previous research there was no default value for the cut values urine levels of IL-6, on research in Denver in 2010 with a value of IL- 6 pieces urine $>75 \mathrm{pg} / \mathrm{ml}$ tested positive whereas on this research based on the ROC curve for a normal distribution of data and results IL- 6 examination of urine tested positive when $>5.854 \mathrm{pg} / \mathrm{ml}$ based on the ROC curve [16].

On the research conducted in Sweden in 1996 with a sample size of 100 infants consisted of 61 infants with pyelonephritis and 31 infants with asymptomatic bacteriuria, where the levels of IL-6 increases urine in infants with urinary tract infections and asymptomatic bacterial Urine the value of urinary IL-6 $\geq 20$ $\mathrm{pg} / \mathrm{ml}$ tested positive [17], while research in Sweden in 1997, declared an increase in IL- 6 in the urine in the first 24 hours of infection and remained elevated after 6 hours of the start of therapy and increased serum IL- 6 in patients older bacterinemia [18]. On this research IL- 6 urine examination performed only once because this research is cross-sectional research.

Interleukin-6 urine researched for a quick examination on the new pyelonephritis was first performed at the University of Sumatera Utara education centers and Haji Adam Malik Hospital Medan. This research was expected to be an additional reference checks accuracy of IL- 6 urine examination has been done before. The limitation of this research is the short-time research and the small number of samples even though the minimum number of samples has been fulfilled. It is expected that in the future this research dating can be done in the long term as well as a greater number of samples, so the results obtained sensitivity and better specificity IL-6 so that urine can be considered as a quick examination of the occurrence of pyelonephritis in neonates and children.

\section{Conclusion}

Interleukin-6 urine examination result has a low accuracy in enforcing pyelonephritis in neonates. Yeast cell growth of Candida in urine neonates, researchers suggest that regular replacement swaddling so the risk for urinary tract infection can be avoided and prevented.

\section{References}

1. Sastre JBL, Aparicio AR, Cotallo GDC, Colomer BF, Hernandez MC (2007) Urinary tract infection in the newborn: clinical and radio imaging studies. Pediatr Nephrol 22(10): 1735-1741.

2. Amelia N, Amir I, Trihono PP (2005) Urinary tract infection among neonatal sepsis of late-onset in Cipto Mangunkusumo Hospital. Paediatr Indones 45(5): 217-222.

3. Shaikh N, Morone NE, Lopez J, Chianese J, Sangvai S, et al. (2009) Does This Child Have a Urinary Tract Infection? JAMA 298(24): 2895-2904.

4. Pecile P, Miorin E, Romanello C, Falleti E, Valent F, et al. (2004) Procalsitonin: A marker of severity of acute pyelonephritis among children. Pediatrics 114(2): e249-254.

5. Pardede SO, Tambunan T, Alatas H, Trihono PP, Hidayati EL (2011) Konsensus infeksi saluran kemih pada anak. In: Pardede So, et al. (Eds.), Badan Penerbit Ikatan Dokter Anak Indonesia. Indonesia, pp. 1-7.

6. Zorc JJ, Kiddoo DA, Shaw KN (2005) Diagnosis and management of pediatric urinary tract infections. Clin Microbiol 18(2): 417-422.

7. National Collaborating Centre for Women's and Children's Health (2007) Urinary tract infection in children diagnosis, treatment and long-term management. National Institute for Health and Clinical Excellence: Guidance, London.

8. Obi B, Sinha M (2007) Diagnosis and treatment of urinary tract infection in children. Prescriber pp. 66-71.

9. Cataldi L, Zaffanello M, Gnarra M, Fanos V (2010) Urinary tract infection in the newborn and the infant : state of the art. J Matern Fetal Neonatal Med 23(S3): 90-93.

10. Rusdidjas, Ramayati R (2002) Infeksi saluran kemih. In: Alatas H, Tambunan T, Trihono PP, Pardede SO (eds.) Buku Ajar Nefrologi Anak edisi 2. Balai Penerbit FKUI. 7: 142-163.

11. Giovanni M, Kjell T, Ian H (2011) Febrile urinary tract infections in children. N Engl J Med 365(3): 293-250.

12. Elder JS (2007) Urinary tract infections. In: Kliegman RM, Behrman RE Jenson HB, Standon BF (eds.) Nelson Textbook of Pediatrics (18 ${ }^{\text {th }}$ edn). USA 538: 2223-2228.

13. Alan RW (2004) Pediatric urinary tract infection. EAU Update 2: 94100.

14. Twajj M (2000) Urinary tract infection in children: A Review of its pathogenesis and risk factors. J R Soc Promot Health 120:220-226.

15. Kauffman CA, Fisher JF, Sobel JD, Newman CA (2011) Candida urinary tract infections-diagnosis. Clin Infect Dis 52(S6): S452-S456.

16. Otto G, Braconier JH, Andreasson A, Svanborg C (1999) Interleukin-6 and disease severity in patients with bacterimic and nonbacterimic febrile urinary tract infection. J Infect Dis 179: 172-179.

17. Benson M, Jodal U, Agace W, Hellstrom M, Marild S, et al. (1996) Interleukin-6 and interleukin-8 in children with febrile urinary tract infection and asymptomatic bacteriuria. JInfect Dis 174(5): 10801084.

18. Dennen P, Altman C, Kaufman J, Klein CL, Hernando AA, et al. (2010) Urine interleukin- 6 is an early biomarker of acute kidney injury in children undergoing cardiac surgery. Critical Care 14(5): R181. 
(C) This work is licensed under Creative

$\begin{array}{ll}\text { (CC) Commons Attribution 4.0 License } \\ \text { BY } & \text { DOI: 10.19080/JOJUN.2017.1.555574 }\end{array}$

\section{Your next submission with Juniper Publishers} will reach you the below assets

- Quality Editorial service

- Swift Peer Review

- Reprints availability

- E-prints Service

- Manuscript Podcast for convenient understanding

- Global attainment for your research

- Manuscript accessibility in different formats

( Pdf, E-pub, Full Text, Audio)

- Unceasing customer service

Track the below URL for one-step submission https://juniperpublishers.com/online-submission.php 